\title{
The Illusion of Perfect Justice
}

\author{
Christian Tomuschat
}

\begin{abstract}
The judgment of the Italian Constitutional Court (ItCC) of 22 October 2014 has set a bad precedent for international law by denying the implementation, within Italy, of the judgment of the International Court of Justice (ICJ) of 3 February 2012. The ICJ found that Italian courts and tribunals had violated German jurisdictional immunity by entertaining suits brought by Italian citizens against Germany on account of damages caused by war crimes committed during World War II by German occupation forces. According to a well-consolidated rule of general international law, no state may be sued before the courts of another state with regard to acts performed in the exercise of its sovereign power. In contravention of Article 94 of the UN Charter, the ItCC deemed it legitimate to discard that ruling because of the particularly grave character of many of the violations in question. It proceeded from the assumption that the right to a remedy established under the Italian Constitution was absolute and must apply even where the financial settlement of the consequences of armed conflict is at issue. However, it has failed to show the existence of any individual reparation claims and has omitted to assess the issue of war reparations owed by Germany in their broader complexity. The judgment of the ItCC might be used in the future as a pretext to ignore decisions of the World Court.
\end{abstract}

\section{Preliminary Observations}

Battles of the past should not be endlessly continued. Unfortunately, the dispute between Germany and Italy concerning the settlement of the damages caused during the occupation of Italy by the German Wehrmacht from September 1943 to May 1945 seems to have all the ingredients of an interminable confrontation where positions of principle clash with no end in sight. Though World War II (WWII)

\footnotetext{
C. Tomuschat $(\bowtie)$

Humboldt University of Berlin, Faculty of Law, Berlin, Germany 
lies more than 70 years in the past, the scars it has left have not led to the healing of the bitter wounds which that war inflicted on all of those involved-primarily the victims of deliberate persecution but also those who have had to endure the consequences of a war that was, from its very inception, criminal.

Let me make clear that no attempt will be or can be made to provide excuses for the bitter fate that struck the Italian citizens who brought actions for financial compensation against Germany, actions that eventually led to the surprising and even revolutionary outcome of the judgment of the Italian Constitutional Court (ItCC) of 22 October 2014, ${ }^{1}$ which held that under Italian constitutional law the judgment of the International Court of Justice (ICJ) of 3 February $2012^{2}$ could not be executed. Whatever judges may decide, the fact is that the German military and security forces gravely violated the applicable regime of humanitarian law. More than mere wrongdoing, this was a breach of the standards of civilization that can claim a venerable and consolidated tradition in Europe. The Nazi regime led Germany into an abyss of criminal conduct before the war machine, once set into motion, rolled back and crushed the German people themselves. Fortunately, we do not here have to argue about historical developments; we need only take note of them in a spirit of objectivity while reflecting on remedial action.

Much has already been written about that seminal ItCC judgment and its consequences. As an outside observer, one easily gets the impression that almost every Italian expert in the field, constitutionalists and internationalists alike, felt compelled to comment on the new course chosen by the ItCC in its approach to international law, as primarily determined by Article 10 of the Italian Constitution. I have made a great effort to inform myself about all of those reactions to the ItCC's findings, leggendo pure i più sottili commenti in lingua giuridica italiana. Nonetheless, I cannot pretend that I have read every single article, note and comment. Yet the overall picture seems to be fairly clear. ${ }^{3}$ I sincerely hope that I have been able to collect and assess all relevant facts without overlooking essential details.

A second clarification should be put forward at this moment. Not being a specialist of Italian constitutional law, it is not my intention to engage in a discussion about the way in which the ItCC, in its examination of the constitutionality of the relevant norms, assessed the customary rule of jurisdictional immunity under international law. Generally, such review is designed to scrutinize the constitutionality of parliamentary statutes of national origin with the Constitution (Article 134). In any event, it was inconceivable to declare Article 10 of the Constitution-the dooropener for the general rules of international law-unconstitutional without introducing a new theory about the core substance of the Constitution being placed at a

\footnotetext{
${ }^{1}$ Corte Costituzionale, Judgment of 22 October 2014, No 238/2014.

${ }^{2}$ ICJ, Jurisdictional Immunities of the State (Germany v Italy: Greece intervening), Judgment of 3 February 2012, ICJ Reports 2012, 99.

${ }^{3}$ See also Christian Tomuschat, 'The National Constitution Trumps International Law', Italian Journal of Public Law 6 (2014), 189-196.
} 
higher hierarchical level. The ItCC found indeed another, more sophisticated way to block the access of the principle of immunity to the Italian domestic legal order.

\section{The Surprise: Silence on the Main Issues}

First, the very heart of the dispute centres around the existence of reparation claims against Germany that have allegedly arisen for individual victims of the measures taken by the Nazi authorities in violation of international humanitarian law (IHL). But the ItCC nowhere raised or answered the question of whether such entitlements could have emerged as a consequence of German governmental wrongdoing. It stands to reason that the ICJ was not seized with the issue. The only charge brought by Germany consisted of the allegation that Italy had infringed her sovereign right of jurisdictional immunity. Accordingly, the ICJ could not go into an issue pertaining to the merits of the cases pending before the Italian courts and tribunals. ${ }^{4}$ On the other hand, by insisting on the imperative requirement that a legal right must be enforceable, the ItCC would have been obligated in good logic to state in unambiguous terms that such individual entitlements to reparation had to be recognized in law. Yet it has failed to raise this issue-which is obviously a fairly complex one since the doctrine of individual human rights is a post-WWII invention. The doctrine of controlimiti, however, cannot bring into being a right against a foreign state.

Second, the ItCC has failed to mention that those who chose to sue Germany before Italian courts and tribunals had an actual opportunity to bring their claims before the German judicial system. Some of the claimants did indeed pursue that course, rising up to the level of the German Constitutional Court. Eventually, all those claims were dismissed as unfounded as to their merits. ${ }^{5}$ Thus, remedies were in fact made available. It is a mistake to confound the availability of a remedy with its well-foundedness. ${ }^{6}$

Third, as far as the substantive aspects of the complex legal configuration are concerned, the ItCC has not regarded it opportune to mention that the case before it was part of a complex puzzle: the settlement of all the substantive consequences entailed by WWII in the absence of a legal instrument explicitly called a Peace Treaty.

\footnotetext{
${ }^{4}$ The few observations in ICJ, Jurisdictional Immunities (n 2), para 104, amount to no more than a signal of sympathy for the victims. For a different perspective, see Paolo Palchetti, chapter 'Right of Access to (Italian) Courts über alles?', in this volume.

${ }^{5}$ Bundesverfassungsgericht, Order of 28 June 2004, 2 BvR 1379/01, BVerfGK 3, 277, paras 29, 37; Verwaltungsgericht Berlin, Judgment of 9 September 2004, 9 A 336.02, para 52. In this context see also the Distomo cases where German courts dismissed claims brought by Greek victims of WWII massacres: Bundesverfassungsgericht, Order of 15 February 2006, 2 BvR 1476/03, BVerfGK 7, 303, paras 12, 17.

${ }^{6}$ See also Alessandro Bufalini, chapter 'Waiting for Negotiations', and Sabino Cassese, chapter 'Recollections of a Judge', in this volume. For a different perspective see Valerio Onida, chapter 'Moving Beyond Judicial Conflict in the Name of the Pre-eminence of Fundamental Human Rights', in this volume.
} 


\section{Challenge to a Foundational Rule of International Law}

Sentenza 238/2014 stands out uniquely in the history of international law. There have been other judgments of the ICJ that were ignored by the losing party; ${ }^{7}$ the refusal of the American authorities to obey the injunctions of the ICJ in the LaGrand case, ${ }^{8}$ for example, is fresh in every international lawyer's mind. Those confrontations, however, were of an incidental character and centring on individual cases. Never before has a domestic court by refusing to follow a pronouncement of the ICJ challenged a generally recognized rule of customary international law. This deeper challenge to the international legal community transcends the underlying controversy between Italy and Germany and its consequences are unfathomable. Lawyers in the US have already woken up and are considering initiating proceedings against former European colonial powers relating back to occurrences more than a hundred years ago. ${ }^{9}$

The ItCC has carefully avoided criticizing the ICJ itself by pointing to alleged errors or other imperfections in its reasoning. Only the Tribunale di Piacenza ventured to take that more direct course by holding without hesitation that the ICJ had not fully understood what stage the development of international law had reached in our contemporary epoch: it invented a class of 'super primacy' norms protecting human life and human dignity. ${ }^{10}$ Yet, notwithstanding the politeness of the ItCC's views, they nonetheless contain a strong implicit element of criticism, as noted, for instance, by Riccardo Pisillo Mazzeschi. ${ }^{11}$ Formally, however, no

\footnotetext{
${ }^{7}$ See Raffaela Kunz, chapter 'Teaching the World Court Makes a Bad Case', in this volume.

${ }^{8}$ ICJ, LaGrand Case (Germany v United States of America), Judgment of 27 June 2001, ICJ Reports 2001, 466 .

${ }^{9}$ See, eg, Sidney L Harring, 'The Herero Demand for Reparations from Germany: The Hundred Year Old Legacy of a Colonial War in the Politics of Modern Namibia', in Max Du Plessis/Stephen Peté (eds), Repairing the Past?: International Perspectives on Reparations for Gross Human Rights Abuses (Antwerpen: Intersentia 2007), 437-450.

${ }^{10}$ Tribunale di Piacenza, Judgment of 28 September 2015, No 723/2015, 1, 12. One might argue that the 2004 Ferrini Judgment by the Corte di Cassazione already contained a similar statement: 'Para 9: Indeed, these are crimes that consist of the particularly intense or systematic violation of basic human rights (...), which are protected by non-derogable norms that stand at the apex of the international legal system, taking precedence over all other norms, whether of conventional or customary nature (...) and therefore also over those norms governing immunity. Para 9.1: The recognition of immunity from jurisdiction for States that are responsible for such offences is in blatant contrast with the normative framework outlined above, since this recognition obstructs rather than protects such values, the protection of which is rather to be considered, in accordance with such norms and principles, essential for the entire international community (...). Moreover, there can be no doubt that this antinomy must be resolved by giving precedence to the higherranking norms' (Translation taken from Yale Law School, Documents Collection Center, available at https://documents.law.yale.edu/sites/default/files/ferrini_v._germany_-_italy_-_2004.pdf). The important difference, however, lies in the fact that at the time of the Ferrini Judgment no prior authoritative international judgment existed concerning the specific matter at hand.

${ }^{11}$ Riccardo Pisillo Mazzeschi, 'La sentenza n. 238/2014 della Corte costituzionale ed i suoi possibili effetti sul diritto internazionale', Diritti umani e diritto internazionale 9 (2015), 23-40, at 39. In the
} 
reproach can be levelled at the ItCC. It has acted consistently within the framework of dualism chosen as its point of departure, confining itself to pronouncing on the effect of the immunity rule within the Italian domestic legal order. Both Heinrich Triepel and Dionisio Anzilotti would have been happy with that methodological approach. This chapter, by contrast, is confined to looking into the ItCC's position under international law.

We do not know whether the ItCC was really satisfied with its feat. The sole fact that it had to admit its solitary stance, standing alone in a world that overwhelmingly recognizes the principle of the jurisdictional immunity of states in respect of acts iure imperii, may indeed provide insufficient grounds for satisfaction. In this regards, it is certainly not improper to recall that every judicial body is made up of individual members and that opinions may reasonably have diverged as to the suitability of launching a head-on attack against the principle of jurisdictional immunity. ${ }^{12}$ In any event, attention must be drawn to the jurisprudence of the European Court of Human Rights (ECtHR), which in Jones $v$ UK ruled only a few months before Sentenza $238 / 2014$ that even in instances of alleged torture the rule of immunity applies, shielding the alleged governmental offender against suits brought against it before the civil courts of foreign countries. ${ }^{13}$ The voice of the ECtHR epitomizes the European concept of human rights and would certainly have deserved being taken into account by the ItCC. Even for a constitutional court it is hard to argue that its national standard concerning legal remedies is higher and more demanding than what at the world level and at the European level is considered to be in full conformity with the rule of law. Persuasive grounds would have to be adduced to show that Italy exceeds every other nation in protecting the right to a remedy where a major human rights violation has occurred. In this regard, however, the judgment is poorly motivated.

Additionally, inconsistencies are visible in the Italian practice itself. Reference must be made to the Markovic case where the Corte di Cassazione dismissed an application for reparation of damages suffered in the former Yugoslavia during the so-called 'Kosovo War' and, it is alleged, with the complicity of Italy as a state member of NATO. The Court held that it was not the function of the judiciary to protect individuals from acts of aerial warfare since such acts were the expression of a 'political function'. ${ }^{14}$ Accordingly, the merits of the case were not considered. In Sentenza 238/2014 the ItCC deemed it unnecessary to mention this earlier pronouncement although it had been issued by the highest instance in civil matters. Furthermore, attention should be paid to the 2008 Treaty of Friendship, Partnership, and Cooperation between Italy and Libya, whose section II under the title 'Closure

\footnotetext{
same vein Riccardo Pavoni, 'Simoncioni v. Germany', American Journal of International Law 109 (2015), 400-406, at 403.

${ }^{12}$ See Sabino Cassese, chapter 'Recollections of a Judge', in this volume.

${ }^{13}$ ECtHR, Jones and Others $v$ The United Kingdom, Judgment of 14 January 2014, Applications Nos 34356/06 and 40528/06.

${ }^{14}$ Corte di Cassazione, Order of 5 June 2002, No 8157/2002.
} 
of the Chapter of the Past and of the Pending Disputes' is conceived as a final settlement against the payment by Italy of US\$5 billion spread over 20 years. ${ }^{15}$ All the monies pledged were designed for infrastructural projects. No reparation payments were set aside for the benefit of the victims of Italian warfare in Libya.

All this casts serious doubts over the central thesis of the ItCC that the right to a remedy, as stipulated in Article 24 of the Italian Constitution, has the high rank attributed to it by the ItCC. International practice has very rarely resorted to reparation measures to the benefit of individual victims after disastrous occurrences like wars or other types of armed conflicts. Primary and secondary rules have to be distinguished. A value judgment can only be attached to the infringement of a primary rule depending on the inherent character of the protected interests. The killing of a human being in violation of the right to life amounts to a serious breach either of IHL or of international human rights law (IHRL), entailing a duty of compensation and possibly also the duty to prosecute the perpetrator. But the obligation to make the required compensation payment, although undoubtedly constituting a commitment under international law, does not amount to a ius cogens rule. States, including wrongdoing states, have a large discretion as to the ways and means to acquit their debt.

\section{Jurisdictional Immunity: An Essential Structural Element of International Law}

Regarding the core issue of the compatibility of a legal enactment excluding individual claims against a foreign state, the ItCC has evolved an abstract concept of precedence of core human rights guarantees by narrowing down the complexity of the factual constellation at stake to such an extent that the key issues have remained invisible. Deliberately, or else by lack of oversight, the ItCC has constructed a strictly binary opposition between on the one hand a principle of the Italian constitutional law and, on the other, the international law principle of jurisdictional immunity. The ItCC sees this relationship as a confrontation between a good and modern human rights principle and a formalistic traditional rule that serves to shield the sovereign power interests of states against any curtailment. No serious effort is made to analyze the principle of jurisdictional immunity as to its inherent qualities. The ItCC does not see that jurisdictional immunity constitutes an essential element of the current system of international law based on sovereign equality.

\footnotetext{
${ }^{15}$ Trattato di Amicizia, 'Partenariato e Cooperazione tra la Repubblica Italiana e la Grande Giamahiria Araba Libica Popolare Socialista' (Benghazi, 30 August 2008), available at www. camera.it/_dati/leg16/lavori/schedela/apritelecomando_wai.asp?codice=16pd10017390.
} 
Most of the Italian commentators have followed the ItCC on this. ${ }^{16}$ They discuss at length the tension between a human rights guarantee and the principle of sovereign equality without ever reflecting on what interest the international community, as it is framed today, has in separating from one another the areas of jurisdiction of the states currently in existence. Many authors recall the leading role of Italian and Belgian courts, in the first half of the twentieth century, in pushing ahead with the now consolidated distinction between acta iure gestionis and acta iure imperii, purporting to suggest that the road hitherto pursued can simply be continued: in the same way as commercial activities were submitted to the scrutiny of foreign courts, acta iure imperii could also be made subject to control by foreign courts. ${ }^{17}$ This reasoning, which also underlies Sentenza $238 / 2014,{ }^{18}$ is fundamentally flawed. Where a state, through its government or special commercial agencies, enters the market, it cannot on plausible grounds claim benefits that are withheld to other market actors. However, when a state has acted in pursuit of its political choices, scrutiny of such acts will inevitably create tensions. No state is prepared to see its governmental conduct supervised by the judiciary of another country and appropriate reparation being imposed upon it. By attributing to each state its own sphere of jurisdiction and establishing rules for the settlement of cross-boundary disputes, international law contributes to upholding peace in interstate relations. ${ }^{19}$

When an armed conflict is waged on foreign territory, jurisdictional competences enter into conflict. In principle, territorial sovereignty prevails. But the armed forces of the foreign state do not forfeit their status as state organs. They retain this status, which does not yield completely to the territorial sovereignty of the adversary. International law has established rules and principles with a view to disentangling this imbroglio. Accordingly, armed conflict has become a phenomenon governed by international law. The consequences flowing therefrom must therefore be settled according to the rules and mechanisms of international law. No state can decide unilaterally what legal implications derive from such occurrences. The ancient

\footnotetext{
${ }^{16}$ See inter alia Gaetano Silvestri, 'Sovranità vs Diritti Fondamentali', Questione Giustizia 1 (2015), 57-63, at 60-63; Paolo Passaglia, 'Una sentenza (auspicabilmente) storica: la Corte limita l'immunità degli Stati esteri dalla giurisdizione civile', Diritti Comparati, (28 October 2014), available at www.diritticomparati.it/una-sentenza-auspicabilmente-storica-la-corte-limitalimmunita-degli-stati-esteri-dalla-giurisdizion/.

${ }^{17}$ See inter alia Tobia Cantelmo/Valentina Capuozzo, 'Tra Immunità e Contro-Limiti: un nuovo Traguardo della Giurisprudenza Italiana in Corte Costituzionale Sentenza n. 238/2014 e Ordinanza n. 30/2015', Rivista di Diritto Pubblico Italiano, Comparato, Europeo 1 (2016), 1-27, at 5, 9, 10, 14, 27; Andrea Guazzarotti, 'Il Paradosso della Ricognizione delle Consuetudini Internazionali. Note Minime a Corte Cost. n. 238 del 2014', Forum di Quaderni Costituzionali, (5 November 2014), available at www.forumcostituzionale.it/wordpress/wp-content/uploads/2014/11/ guazzarotti_nota_238_2014.pdf, 1-4, at 1-3; Passaglia, 'Una sentenza (auspicabilmente) storica' 2014 (n 16).

${ }^{18}$ See ItCC, Judgment 238/2014 (n 1), para 3.3.

${ }^{19}$ In this vein, see ICJ, Jurisdictional Immunities (n 2), para 57.
} 
doctrine of subjugation or debellatio, ${ }^{20}$ according to which a defeated state could be deprived of any rights, a dead body delivered to the arbitrariness of the victors, has become defunct and obsolete as it could not be reconciled with the now wellestablished principle of self-determination.

\section{The Different Methods of Reparation}

The ItCC has failed to perceive that in our time alternative methods are available for satisfying the demands of an injured state. In the present context, two main methods can be discerned. The classic method consists of resorting to intergovernmental mechanisms by relying on the assumption that harm inflicted on the nationals of a state amounts in law to harm done to that state. The government concerned then presents the losses incurred as one comprehensive claim, to be negotiated with the wrongdoing state and possibly ending up in a lump sum agreement. The other method consists of taking account of each and every item of harm, person by person, thus making individual payments to everyone recognized as having suffered damage. General international law does not acknowledge the latter method.

The traditional interstate method was imposed on Germany at the end of WWII. At that time, Germany was not recognized as a sovereign actor with equal rights. This was fully understandable. There was no legitimate representation of the German people during the months following the military surrender on 8 May 1945. The members of the last government of the Nazi Reich had all been arrested. Criminal charges were prepared against them-and rightly so. The political opponents of the Nazi regime having found refuge in other countries had not been able to form a government in exile that could have been recognized as a legitimate representation of the German people and a valid interlocutor with the victorious Allied powers. Therefore, all the mechanisms for the transition from war to peace were established without any effective German presence. At the Potsdam Conference, only the Soviet Union, the UK, and the US were present; not even France was admitted. German voices were neither heard nor consulted, meaning that the interests of the German people were sidelined. When the victorious Allied powers negotiated the peace treaty with Italy in Paris, Germany was also absent while an Italian delegation was admitted and could to the best of its abilities defend Italian interests, although it essentially had to accept the demands of the victorious powers.

Notwithstanding these procedural shortcomings, the negotiators at Potsdam agreed on a mechanism according to which the German war debt was to be settled collectively, according to the traditional method outlined above. The Potsdam Agreement, negotiated and signed only by the three main powers, but intended to become binding for all the former enemy states and the states participating in the

\footnotetext{
${ }^{20}$ See Lassa Oppenheim/Hersch Lauterpacht, International Law: A Treatise (London: Longmans, Vol II, $7^{\text {th }}$ ed 1952), 600-601.
} 
fight against the Axis powers, stated categorically that Germany will 'be compelled to compensate to the greatest possible extent for the loss and suffering that she has caused to the United Nations and for which the German people cannot escape responsibility'. ${ }^{21}$

Details of how the settlement should be effected were laid down in the subsequent provisions of the Potsdam Agreement. Three main items of reparation were considered. First, removals of German industrial equipment were envisaged-and soon carried out in particular in the Soviet zone of occupation. Second, agreement was reached on confiscating all German external assets. And last, the determination was made to separate from Germany one fourth of its national territory and to place it under Polish or Soviet administration with a view to definitively allocating these territories at a later stage to Poland and the Soviet Union under the terms of a final peace treaty. Furthermore, the concomitant expulsion of the population in these regions resulted in the confiscation of all the assets held by the German nationals concerned.

The Potsdam determination was a clear signal: the Allied powers were of the view that the war damages caused by Germany should be compensated by those collective transfers of goods and territories, not by way of providing compensation to each and every victim individually. They acted as trustees for all of the states that had participated in the armed conflict, and for the implementation of their subsequent decisions an Inter-Allied Reparation Agency was established in Paris by agreement among all of the victorious powers. ${ }^{22}$ All the assets removed from Germany were to be registered for the computation of the shares to be distributed to the countries prejudiced by the war. No account was established for Italy since under Article 77 of the Peace Treaty ${ }^{23}$ Italy, having acted as co-aggressor together with Germany, had been denied any right to compensation.

\footnotetext{
${ }^{21}$ Report on the Tripartite Conference of Berlin, 2 August 1945, Truman Paper-Naval Aide Files vol XII (Potsdam Agreement), sec IV.

${ }^{22}$ Agreement on Reparation from Germany, on the Establishment of an Inter-Allied Reparation Agency and on the Restitution of Monetary Gold, 14 January 1946, British Foreign Office Treaty Series, London 1947, No 56.

23، 1 . From the coming into force of the present Treaty property in Germany of Italy and of Italian nationals shall no longer be treated as enemy property and all restrictions based on such treatment shall be removed. 2. Identifiable property of Italy and of Italian nationals removed by force or duress from Italian territory to Germany by German forces or authorities after September 3, 1943, shall be eligible for restitution. 3. The restoration and restitution of Italian property in Germany shall be effected in accordance with measures which will be determined by the Powers in occupation of Germany. 4. Without prejudice to these and to any other dispositions in favour of Italy and Italian nationals by the Powers occupying Germany, Italy waives on its own behalf and on behalf of Italian nationals all claims against Germany and German nationals outstanding on May 8, 1945, except those arising out of contracts and other obligations entered into, and rights acquired, before September 1, 1939. This waiver shall be deemed to include debts, all inter-governmental claims in respect of arrangements entered into in the course of the war, and all claims for loss or damage arising during the war. 5. Italy agrees to take all necessary measures to facilitate such transfers of German assets in Italy as may be determined by those of the Powers occupying Germany which are empowered to dispose of the said assets.'
} 
As is well known, no peace treaty bearing that name was concluded with Germany. The political tensions arising almost immediately after the end of armed hostilities prevented such a formalized end to WWII. Only at the moment of German reunification was it deemed necessary to adopt a punto finale. Germany and the four Allied powers negotiated the Treaty on the Final Settlement with Respect to Germany. ${ }^{24}$ This treaty, although remaining silent about any measure of reparation, was indeed meant to put a definitive end to the issue of reparations. ${ }^{25}$ The great step taken by Germany was the recognition that the territories for many years provisionally placed under Polish and Soviet occupation would henceforth be considered as having passed under the jurisdiction of those countries. On the other hand, by accepting the title of 'Final Settlement', the Allied forces certified that they would be debarred from asserting any further war claims against Germany. In turn, Germany renounced any possible claims against the Allied powers on account of the breaches of humanitarian law committed by them: by attacking civilian objects, bombing cities where no military targets were present, driving out people from their ancestral lands, and thereby causing the death of millions of people.

\footnotetext{
${ }^{24}$ Treaty on the Final Settlement with Respect to Germany, 12 September 1990, 1696 UNTS 115 (Two-plus-Four Treaty).

${ }^{25}$ Ibid, see Preamble: 'The Federal Republic of Germany, the German Democratic Republic, the French Republic, the Union of Soviet Socialist Republics, the United Kingdom of Great Britain and Northern Ireland and the United States of America, Conscious of the fact that their peoples have been living together in peace since 1945; Mindful of the recent historic changes in Europe which make it possible to overcome the division of the continent; Having regard to the rights and responsibilities of the Four Powers relating to Berlin and to Germany as a whole, and the corresponding wartime and post-war agreements and decisions of the Four Powers; Resolved, in accordance with their obligations under the Charter of the United Nations to develop friendly relations among nations based on respect for the principle of equal rights and self-determination of peoples, and to take other appropriate measures to strengthen universal peace; Recalling the principles of the Final Act of the Conference on Security and Cooperation in Europe, signed in Helsinki; Recognizing that those principles have laid firm foundations for the establishment of a just and lasting peaceful order in Europe; Determined to take account of everyone's security interests; Convinced of the need finally to overcome antagonism and to develop cooperation in Europe; Confirming their readiness to reinforce security, in particular by adopting effective arms control, disarmament and confidence-building measures; their willingness not to regard each other as adversaries but to work for a relationship of trust and cooperation; and accordingly their readiness to consider positively setting up appropriate institutional arrangements within the framework of the Conference on Security and Cooperation in Europe; Welcoming the fact that the German people, freely exercising their right of self-determination, have expressed their will to bring about the unity of Germany as a state so that they will be able to serve the peace of the world as an equal and sovereign partner in a united Europe; Convinced that the unification of Germany as a state with definitive borders is a significant contribution to peace and stability in Europe; Intending to conclude the final settlement with respect to Germany; Recognizing that thereby, and with the unification of Germany as a democratic and peaceful state, the rights and responsibilities of the Four Powers relating to Berlin and to Germany as a whole lose their function; Represented by their Ministers for Foreign Affairs who, in accordance with the Ottawa Declaration of 13 February 1990, met in Bonn on 5 May 1990, in Berlin on 22 June 1990, in Paris on 17 July 1990 with the participation of the Minister for Foreign Affairs of the Republic of Poland, and in Moscow on 12 September 1990; Have agreed as follows:'.
} 


\section{The Impossibility of Reparation of War Damages by Individual Actions}

Erroneously, the ItCC has embraced the view that with regard to grave crimes under international law reparation must consist of individual payments to each and every victim of German misconduct. It does not say so openly but the inference is inherent in its insistence on the right to a remedy as a necessary consequence of the infringement of a right. Positive international law, however, does not recognize individual reparation claims. Article 3 of the 1907 Hague Agreement No IV establishes the collective responsibility of the state whose agents have committed an unlawful act. $^{26}$ Indeed, international practice has evolved a pattern according to which mass damages caused by warfare should be settled at the interstate level by agreement between the governments concerned. The bar of jurisdictional immunity favours rational proceedings organized by a victim state by way of diplomatic protection, under which all the individual claims can be aggregated in a systematic fashion according to merit.

It is an illusion to believe that destroying the bar of jurisdictional immunity could become a panacea in instances where grave violations of IHL or IHRL are in issue. First, states against whom foreign courts have delivered compensation judgments would hardly ever honour such judgments. It is remarkable that only a few authors have found it necessary to delve into this highly practical issue. ${ }^{27}$ Encouraging the victims to bring suits against a tortfeasor state may sound eminently constructive and promising. In real terms, however, the successful claimants would not gain anything tangible. They might achieve a moral victory but little else. Judgments against a foreign state can be enforced only with great difficulties, as efforts in recent years to recover monies from Argentina have amply shown. According to the UN Convention on Jurisdictional Immunities of States and their Property, ${ }^{28}$ measures of constraint against state property are admissible only under extremely strict conditions (Article 19) in consonance with firmly established rules of customary law. The ItCC has been wise enough not to challenge these rules, whose non-respect could entail highly adverse consequences for Italy as well. In sum, that great step forward praised by many voices in the legal doctrine commenting on Judgment 238/2014 leads into a vacuum where no real substance can be found. The ItCC may have secured for Italy a moral victory, but it has shattered the foundations of international law by undermining legal certainty in the operation of general international law. The rule

\footnotetext{
${ }^{26}$ See, eg, Bundesgerichtshof (Federal Court of Justice), Judgment of 6 October 2016, III ZR 140/15, BGHZ (Kunduz).

${ }^{27}$ Francesco Francioni, 'Access to Justice and Its Pitfalls', Journal of International Criminal Justice 14 (2016), 629-636, at 634; Paolo Palchetti, 'Can State Action on Behalf of Victims Be the Alternative to Judicial Access to Justice in Case of Grave Breaches of Human Rights?', Italian Yearbook of International Law 24 (2014), 53-60, at 56.

${ }^{28}$ UN Convention on Jurisdictional Immunities of States and Their Property (2 December 2004), UN Doc A/RES/59/83, UN Doc A/59/49, 486 (not yet in force).
} 
of jurisdictional immunity ensures the peaceful exercise of sovereign power according to the paradigm of equality. ${ }^{29}$ Should domestic courts gain the power of interfering in the domestic matters of other states by enjoining them to perform or not perform specific acts, sovereign equality would suffer significant damage. International disputes about controversial issues under international law must be settled by international means of settlement, inter alia, by determinations of international bodies and not by unilateral decisions of one of the parties to the relevant dispute. Nemo judex in re sua.

Coming back to the alternative between the two methods of settlement available within the present-day system of international law, it stands to reason that it is inconsistent to apply the two methods of reparation parallel to one another if not explicitly agreed to by the parties concerned or otherwise consented to by the debtor state. Thus, Germany has always been prepared to provide reparation to individual victims of racial persecution. Israel, in particular, received generous compensation payments, and a specific treaty was concluded with Italy for that purpose. ${ }^{30}$ Generally, however, where the determination is made to resort to the collective method of reparation, to open up at the same time the second avenue would lead to placing a double burden on the wrongdoing state. This brutal truth is unpleasant to hear, since it cannot be denied that those who suffered during the German occupation of Italy have not been palpably compensated as individuals. They feel entitled to be provided with compensation, arguing that they have not benefitted personally from the sacrifices that Germany had to concede under the Potsdam Agreement and its implementation. In this context, the Italian state should have helped its citizens by awarding to them, on its own initiative, appropriate reparation payments, ${ }^{31}$ given the fact that compensation for war damages is a collective responsibility of the national community.

\section{The Hard Task of Seeking an Equitable Peace Settlement}

The ItCC has closed its eyes to the context of the legal issue submitted to its legal cognizance: adjudicating the dispute on the constitutionality of the legal norms barring individual claims against Germany was an element in a comprehensive peace settlement. Settling the consequences of war is an unpleasant undertaking.

\footnotetext{
${ }^{29}$ See ICJ, Jurisdictional Immunities (n 2), para 57.

${ }^{30}$ Agreement between the Federal Republic of Germany and Italy on the Compensation for Italian Nationals Subjected to National-Socialist Measures of Persecution (Bonn, 2 June 1961), German and Italian version published in Bundesgesetzblatt II 5 July 1963 No 22, 791.

${ }^{31}$ Suggested also by Enzo Cannizzaro, 'Judicial Immunity and Judicial Protection: The Decision of the Italian Constitutional Court No. 238 of 2014', Rivista di diritto internazionale 98 (2015), 126-134, at 131; Francioni, 'Access to Justice' 2016 (n 27), 636.
} 
The modern tendency is to grant, as a matter of good policy, comprehensive compensation for the harm endured by all the victims, ${ }^{32}$ notwithstanding the fact that no such entitlements have arisen under positive law. ${ }^{33}$ Additionally, it should not be lost sight that the case at hand dates back more than 70 years to a time when individual claims against a foreign state on account of war damages were simply unheard of.

Establishing a settlement after a war constitutes a collective undertaking. All sides are entitled to come forward with their demands and claims. It is true that the countries attacked by Nazi Germany had suffered the most. At the same time, it is equally true that Italy stood at Germany's side for many years, supporting its aggressive policies. Only in September 1943 did Italy, fortunately, abandon her Berlin ally and join the anti-Axis powers. Had she left the unhappy alliance two years earlier, Hitler might not have had the courage of trying to expand Germany's dictatorial regime to the whole of Europe and the Soviet Union. In any event, if one seeks to establish a just and equitable equilibrium in a peace treaty, account must be taken of the losses suffered on all sides. As hinted at already, 12 million Germans were driven out from their ancestral homes, with millions dying during their flight. ${ }^{34}$ Since the fate and treatment of the Italian prisoners of war were at the core of the dispute before the ICJ, the treatment of German prisoners of war matters too. Contrary to the rules of the 1929 Convention on the Treatment of Prisoners of War (Article 75), Germans captured by Allied forces were not released immediately after the end of hostilities. Russia kept German prisoners until 1955, ten years after the German military surrender on 8 May $1945 .{ }^{35}$ The US and the UK sent more than 600,000 German prisoners of war from their respective zones of occupation to France where they were used as forced labourers. ${ }^{36}$ The last prisoners of war were allowed to return home from France in 1948, three years after the end of hostilities.

\footnotetext{
${ }^{32}$ UN General Assembly, Resolution 60/147 on Basic Principles and Guidelines on the Right to a Remedy and Reparation for Victims of Gross Violations of International Human Rights Law and Serious Violations of International Humanitarian Law, 16 December 2005, remains a recommendation and has not acquired the status of positive international law.

${ }^{33}$ For the position of the German Federal Court of Justice, see Judgment of 6 October 2016 (n 26).

${ }^{34}$ Exhaustive study by Ray M Douglas, Orderly and Humane: The Expulsion of the Germans after the Second World War (New Haven/London: Yale University Press 2012).

${ }^{35}$ See Rüdiger Overmans, Soldaten hinter Stacheldraht: deutsche Kriegsgefangene des Zweiten Weltkriegs (Berlin: Propyläen 2000), 258. It is true, on the other hand, that the treatment of the Soviet prisoners of war in the early stages of the war against the Soviet Union in 1941 is one of the most shameful chapters of the German military history. No adequate measures were taken to protect the captured soldiers by providing them with food and shelter. They were left in almost total abandonment without any care and consequently died in large numbers.

${ }^{36}$ See Kurt W Böhme, Die deutschen Kriegsgefangenen in französischer Hand (Zur Geschichte der deutschen Kriegsgefangenen des Zweiten Weltkrieges, Vol XIII) (Munich/Bielefeld: Verlag Ernst und Werner Gieseking 1971), 14-20.
} 


\section{Looking to the Future}

The most deplorable consequence of Sentenza 238/2014, on the basis of its key determination, would be if WWII were continued at the legal level by all victims of ill-treatment at the hands of a foreign power. This is a consequence that the ItCC has not contemplated or in any event is not explicitly dealt with in its judgment. What Italian victims could or can do in bringing claims against Germany would have to be deemed applicable to German victims of grave violations of IHL as well, or for example to African victims of Italian colonialism. International law is not a two-class legal regime made up of full rights-holders on the one side and persons belonging to a nation that forfeited all of its entitlement on the other. In terms of human rights, equality and non-discrimination are the indispensable building blocks of the effective reign of the rule of law. Consequently, the judgment of the ItCC would make impossible any peace settlement after a major armed conflict that was accompanied by massive violations of international humanitarian law or international human rights law. Every individual victim would keep their presumed or alleged entitlements notwithstanding any lump sum agreement to the contrary. ${ }^{37}$ This would be disastrous for world peace.

The case decided by the ItCC shows that in order to attain equitable peace settlements an impartial third institution is required. Such institutions may be established on a case-by-case basis - which presupposes that the parties involved are more or less of equal political weight—or else the relevant parties would have to turn to existing institutions. Obviously, in functional terms the most appropriate institution today would be the UN Peacebuilding Commission established in 2005 concurrently by the General Assembly ${ }^{38}$ and the Security Council. ${ }^{39}$ Within this Commission, fruitful cooperation of the two main bodies of the UN with any litigant parties can be brought about. The shortcomings of the Peacebuilding Commission are that it was established as an advisory body only, lacking the requisite institutional devices of constraint. Here again it appears that the members of the Security Council and their representatives on the Peacebuilding Commission need to acquire a new sense of responsibility. In fact, even the permanent members of the Security Council hold their seats only as a trust of the international community that has chosen them to ensure the general interest of humankind. Their names were not inscribed in the UN Charter as an invitation to assert, through the Security Council, their own specific interests.

Therefore, the Security Council should assume responsibility in a situation where indicia suggest that the parties involved, if left alone, would not attain a fair settlement by failing to reciprocally take account of the interests of the other side.

\footnotetext{
${ }^{37}$ See Christian Tomuschat, 'Peace Treaties and Jus Cogens', in Christian Calliess (ed), Herausforderungen an Staat und Verfassung. Liber Amicorum für Torsten Stein (Baden-Baden: Nomos 2015), 339-359.

${ }^{38}$ UN General Assembly, A/RES/60/180, 20 December 2005.

${ }^{39}$ UN Security Council, S/RES/1645, 20 December 2005.
} 
The best example of a body that discharged its function with absolute neutrality and fairness is the UN Compensation Commission, which was called upon to settle the consequences of the war waged by Iraq against Kuwait. ${ }^{40} \mathrm{With}$ an astounding degree of sober professionalism, the Commission succeeded in distributing the available assets among the claimants in a fair manner, dividing them into different classes and prioritizing those that asserted relatively small amounts of compensation payments.

The judgment of the ItCC provides a well-intentioned reflection on the relationship between the right to a remedy and the rule of jurisdictional immunity. But it has totally lost sight of the underlying landscape of the disputes. Its solution, which suggests pursuing, in cases of serious international crimes, claims against foreign states on the home ground of the victim contrary to the internationally applicable principle of jurisdictional immunity, leads astray. This would cause considerable prejudice to the legal framework of the international community and, at the end of the day, leave the happy claimants among all of the others who have not been able to obtain an enforceable judgment with empty hands.

\section{References}

Böhme, Kurt W, Die deutschen Kriegsgefangenen in französischer Hand (Zur Geschichte der deutschen Kriegsgefangenen des Zweiten Weltkrieges, Vol XIII) (Munich/Bielefeld: Verlag Ernst und Werner Gieseking 1971)

Cannizzaro, Enzo, 'Judicial Immunity and Judicial Protection: The Decision of the Italian Constitutional Court No. 238 of 2014', Rivista di diritto internazionale 98 (2015), 126-134

Cantelmo, Tobia/Valentina Capuozzo, 'Tra Immunità e Contro-Limiti: un nuovo Traguardo della Giurisprudenza Italiana in Corte Costituzionale Sentenza n. 238/2014 e Ordinanza n. 30/2015', Rivista di Diritto Pubblico Italiano, Comparato, Europeo 1 (2016), 1-27

Douglas, Ray M, Orderly and Humane: The Expulsion of the Germans after the Second World War (New Haven/London: Yale University Press 2012)

Francioni, Francesco, 'Access to Justice and Its Pitfalls', Journal of International Criminal Justice 14 (2016), 629-636

Guazzarotti, Andrea, 'Il Paradosso della Ricognizione delle Consuetudini Internazionali. Note Minime a Corte Cost. n. 238 del 2014', Forum di Quaderni Costituzionali, (5 November 2014), available at https://www.forumcostituzionale.it/wordpress/wp-content/uploads/2014/ 11/guazzarotti_nota_238_2014.pdf, 1-4

Harring, Sidney L, 'The Herero Demand for Reparations from Germany: The Hundred Year Old Legacy of a Colonial War in the Politics of Modern Namibia', in Max Du Plessis/Stephen Peté (eds), Repairing the Past?: International Perspectives on Reparations for Gross Human Rights Abuses (Antwerpen: Intersentia 2007), 437-450

Oppenheim, Lassa/Hersch Lauterpacht, International Law: A Treatise (London: Longmans, Vol II, $7^{\text {th }}$ ed 1952)

Overmans, Rüdiger, Soldaten hinter Stacheldraht: deutsche Kriegsgefangene des Zweiten Weltkriegs (Berlin: Propyläen 2000)

\footnotetext{
${ }^{40}$ Established by the United Nations, Security Council, S/RES/687, 3 April 1991. See also Filippo Fontanelli, chapter 'Sketches for a Reparation Scheme', in this volume.
} 
Palchetti, Paolo, 'Can State Action on Behalf of Victims Be the Alternative to Judicial Access to Justice in Case of Grave Breaches of Human Rights?', Italian Yearbook of International Law 24 (2014), 53-60

Pavoni, Riccardo, 'Simoncioni v. Germany', American Journal of International Law 109 (2015), 400-406

Pisillo Mazzeschi, Riccardo, 'La sentenza n. 238/2014 della Corte costituzionale ed i suoi possibili effetti sul diritto internazionale', Diritti umani e diritto internazionale 9 (2015), 23-40

Silvestri, Gaetano, 'Sovranità vs Diritti Fondamentali', Questione Giustizia 1 (2015), 57-63

Passaglia, Paolo, 'Una sentenza (auspicabilmente) storica: la Corte limita l'immunità degli Stati esteri dalla giurisdizione civile', Diritti Comparati, (28 October 2014), available at https://www. diritticomparati.it/una-sentenza-auspicabilmente-storica-la-corte-limita-limmunita-degli-statiesteri-dalla-giurisdizion/

Tomuschat, Christian, 'Peace Treaties and Jus Cogens', in Christian Calliess (ed), Herausforderungen an Staat und Verfassung. Liber Amicorum für Torsten Stein (BadenBaden: Nomos 2015), 339-359

Tomuschat, Christian, 'The National Constitution Trumps International Law', Italian Journal of Public Law 6 (2014), 189-196

Open Access This chapter is licensed under the terms of the Creative Commons Attribution 4.0 International License (http://creativecommons.org/licenses/by/4.0/), which permits use, sharing, adaptation, distribution and reproduction in any medium or format, as long as you give appropriate credit to the original author(s) and the source, provide a link to the Creative Commons license and indicate if changes were made.

The images or other third party material in this chapter are included in the chapter's Creative Commons license, unless indicated otherwise in a credit line to the material. If material is not included in the chapter's Creative Commons license and your intended use is not permitted by statutory regulation or exceeds the permitted use, you will need to obtain permission directly from the copyright holder.

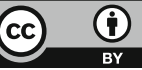

